\title{
Endocrine control of metabolic adaptation during lactation
}

By R. G. VERnon, Hannah Research Institute, Ayr KA6 5HL

This topic has been the subject of a number of recent reviews (e.g., Bauman \& Elliot, 1983; Collier et al. 1984; Forsyth, 1986; Williamson, 1986; Girard et al. 1987; Vernon, 1988). In this brief essay I have therefore focused mainly on recent developments, especially in changes in endocrine responsiveness of tissues with lactation. In addition, I have tried to highlight some of the important differences and similarities between domestic ruminants and laboratory rodents in their metabolic adaptations and their endocrine control during lactation.

\section{Adaptations}

Lactation in both rodents and ruminants increases nutrient requirements-nutrient output in milk may equal or exceed nutrient utilization by the rest of the body! This considerable challenge is met primarily by increasing food intake and also the capacity to digest, absorb and process the additional nutrients in both types of species (Table 1). However, adaptations of liver metabolism are markedly different in rodents and ruminants (Table 2), reflecting differences in nutrients absorbed; there is a massive increase in glucose absorption in rats and mice whereas, as a result of rumen fermentation, little or no glucose is absorbed in ruminants, while in both glucose requirements are greatly increased for lactose synthesis.

The need for additional nutrients is decreased by certain adaptations. A major energy-saving device in rodents is a decrease in non-shivering thermogenesis (Trayhum, 1985); this arises from both a diminished capacity of brown adipose tissue to produce heat (Trayhurn \& Jennings, 1987) and a decrease in sympathetic nervous activity in the tissue (Trayhurn \& Wusteman, 1987) during lactation. There does not appear to be any brown adipose tissue in ruminants, hence this option is not available. However, in both ruminants and rodents there is a decrease in the rate of lipid synthesis and in the capacity (i.e., activity of limiting enzymes) for lipid synthesis in white adipose tissue (see Bauman \& Elliot, 1983; Vernon \& Flint, 1984; Williamson, 1986; Vernon, 1988), which both decreases the requirement for lipid precursors and also ensures their preferential

Table 1. Effect of lactation on food intake and its handling

$\begin{array}{lcc}\text { Appetite } & \text { Rodents } & \text { Ruminants } \\ \text { Gastrointestinal tract } & \uparrow & \uparrow \\ \text { Size } \\ \text { Absorptive capacity } & \uparrow & \uparrow \\ \text { Hepatic portal vein } \\ \quad \text { Blood flow } \\ \text { Liver Size } & \uparrow & \uparrow \\ \quad & \uparrow & \uparrow\end{array}$

$\uparrow$, Variable increased during lactation; results from Vernon (1988) and Williamson (1980). 
Table 2. Metabolic adaptation to lactation in liver, adipose tissue and muscle

$\begin{array}{llcc}\text { Tissue } & \text { Variable } & \text { Rodents } & \text { Ruminants } \\ \text { Liver } & \text { Glucose utilization } & \uparrow & ? \\ & \text { Gluconeogenesis } & - & \uparrow \\ & \text { Lipogenesis } & \uparrow & ? \\ & \text { Fatty acid esterification } & \uparrow & - \\ & \text { Ketogenesis } & \downarrow & ? \\ \text { Adipose tissue } & \text { Protein synthesis } & \uparrow & \downarrow \\ & \text { Glucose utilization } & \downarrow & \downarrow \\ & \text { Lipoprotein lipase } & \downarrow & \downarrow \\ & \text { Lipogenesis } & \downarrow & \uparrow \\ \text { Skeletal muscle } & \text { Lipolysis esterification } & \downarrow & \downarrow \\ & \text { Glucose utilization } & \uparrow & \uparrow \\ & \text { Protein synthesis } & & \\ & \text { Protein degradation } & -? & \end{array}$

$\uparrow, \downarrow,-$, Variable increased, decreased or unchanged during lactation respectively; ?, not known if variable changes; results from Williamson (1986) and Vernon (1988).

utilization by the mammary gland. Also triacylglycerol turnover is diminished in white adipose tissue in both rats (Hansson et al. 1987) and ruminants (Vernon, 1988). In contrast, there does not appear to be any decrease in protein turnover in muscle in rodents (Siebrits et al. 1985; Millican et al. 1987) or in ruminants (see Vernon, 1988), despite protein turnover making a greater contribution to the energy requirement of an animal than triacylglycerol turnover (Garlick, 1986), suggesting that there is further potential for economy. Curiously, in the mouse, protein turnover is actually increased during lactation, mostly due to changes in liver and gut metabolism (Millican et al. 1987); this is probably a response to hyperphagia, but nevertheless this increased turnover must contribute to the additional energy requirement of lactation.

Despite some adaptations which decrease nutrient utilization by the rest of the body, the increase in food intake or the rate of increase in food intake may be insufficient to meet the demands of the mammary gland, hence there may be some mobilization of tissue reserves, especially adipose tissue triacylglycerol (over half the reserves of lipid may be lost during lactation in both rodents and ruminants, see Vernon \& Flint, 1984). In addition, there may be smaller loss of protein and minerals (see Bauman \& Elliot, 1984; Vernon, 1988). Mobilization of reserves can make a substantial contribution to milk production both in domestic ruminants (Bauman \& Elliot, 1983) and in rodents (Weiner, 1987).

\section{Serum hormone concentrations}

Lactation perturbs the endocrine system in both rodents and ruminants (Table 3); a major difference, however, is the rise in serum growth hormone in ruminants (see Bauman \& Elliot, 1983; Collier et al. 1984) which is not found in rodents (Schalch \& Reichlin, 1966; R. J. Madon \& D. J. Flint, unpublished results). A high serum prolactin concentration is critical for lactation in rodents, but appears to be less important in ruminants once lactation is established (Forsyth, 1986). In contrast, growth hormone is thought to be critical for lactation in ruminants (Forsyth, 1986) but, except around peak 
Table 3. Changes in serum hormone concentration during lactation

$\begin{array}{lcc}\text { Hormone } & \text { Rodents } & \text { Ruminants } \\ \text { Prolactin } & \uparrow & \uparrow \\ \text { Growth hormone } & - & \uparrow \\ \text { Insulin } & \downarrow & \downarrow \\ \text { Glucagon } & - & -\end{array}$

$\uparrow, \downarrow,-$, Variable increased, decreased or unchanged by lactation respectively. Results from Williamson (1980), Forsyth (1986) and Vernon (1988).

lactation (D. J. Flint \& R. G. Vernon, unpublished results), does not appear to be essential for lactation in rodents (Madon et al. 1986). Prolactin and growth hormone differ in their target tissues, prolactin acting directly on the mammary gland and the liver but not on adipocytes, whereas growth hormone acts directly on adipocytes and the liver but not on the mammary gland (see Vernon, 1988). Growth hormone, however, stimulates the production of insulin-like growth factor-1 (IGF-1) by the liver, and this appears to act directly on the mammary gland (see p. 28). In rats, prolactin also stimulates the release from the liver of a peptide (synlactin) which appears to act on the mammary gland (Nicoll et al. 1985), but it is not known if it acts on other tissues. These various interactions are summarized in Fig. 1.

Lactation results in hypoinsulinaemia in both rodents and ruminants (see Williamson 1980; Vernon, 1988), but curiously the mechanisms responsible appear to differ. In cattle the pancreas becomes less responsive to insulinotropic agents (Lomax et al. 1979), whereas in the rat pancreatic response remains normal (Madon et al. 1985) and it is thought that the hypoinsulinaemia arises from a combination of a lower glucose concentration in the portal vein and destruction of insulin by the mammary gland (Jones et al. 1984).

\section{Tissue responsiveness to hormones}

Lactation not only results in an altered serum hormone profile, it also leads to an altered ability of some tissues to respond to hormones. Changes may involve alterations in response (maximum effect) or sensitivity (concentration of hormone required to achieve half-maximum effect), or both.

Insulin action. The ability of insulin to stimulate glucose utilization (Ferre et al. 1986; Burnol et al. 1987) and its conversion to fatty acids (Burnol et al. 1983) in vivo in both white and brown adipose tissue is diminished in the lactating rat, while the ability of insulin to activate pyruvate dehydrogenase $(E C 1.2 .2 .2,1.2 .4 .1)$ in vivo in white adipose tissue is lost completely (Kilgour \& Vernon, 1987). An impaired response to insulin has also been observed in vitro in white adipocytes from lactating rats (Burnol et al. 1986a) and in white adipose tissue from sheep (Fig. 2). In both the rat (Burnol et al. 1986a) and sheep (Fig. 2) the ability of insulin to stimulate lactate production in white adipose tissue is unimpaired by lactation. Thus, there is a selective impairment of insulin action in the tissue. One difference between the rat and the sheep is that in the rat the impairment appears to be a decreased response to insulin, whereas in sheep adipose tissue there is a loss of both response and sensitivity to the hormone (Fig. 2). Some at least of these metabolic impairments probably arise from the failure to activate pyruvate dehydrogenase (Kilgour \& Vernon, 1987), but in addition insulin also failed to activate acetyl-CoA carboxylase ( $E C$ 6.4.1.2) in adipose tissue from lactating sheep (Vernon et al. 1988). 
Rodents

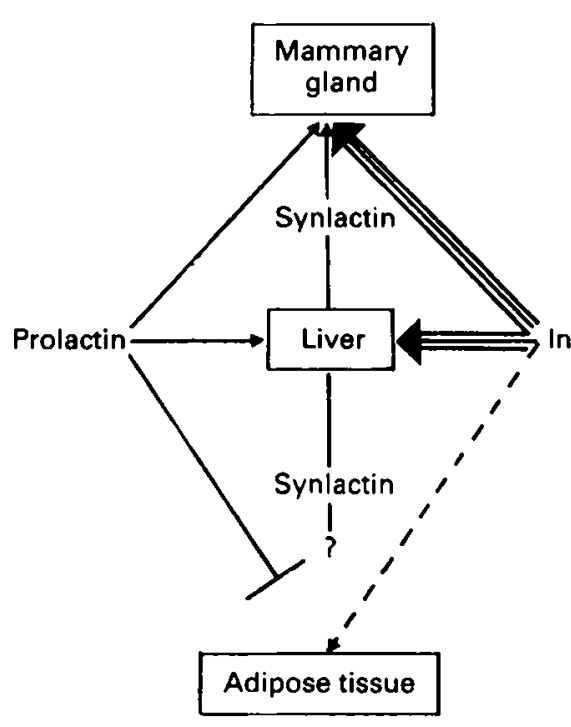

\section{Ruminants}

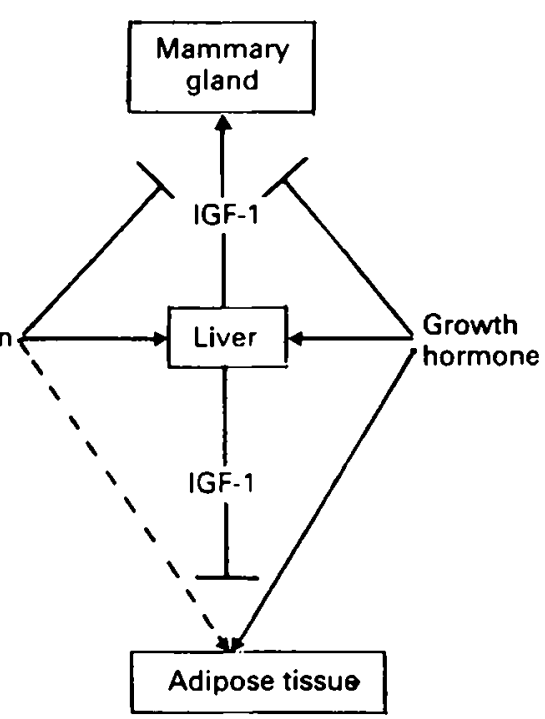

Fig. 1. Some target tissues of prolactin, growth hormone, insulin (acute effects), insulin-like growth factor-1 (IGF-1) and synlactin in lactating rodents and ruminants. $\longleftarrow, \vdash$, Target tissue and non-target tissue respectively; $\equiv,+\cdots$, tissue becomes more or less sensitive respectively to hormone during lactation.

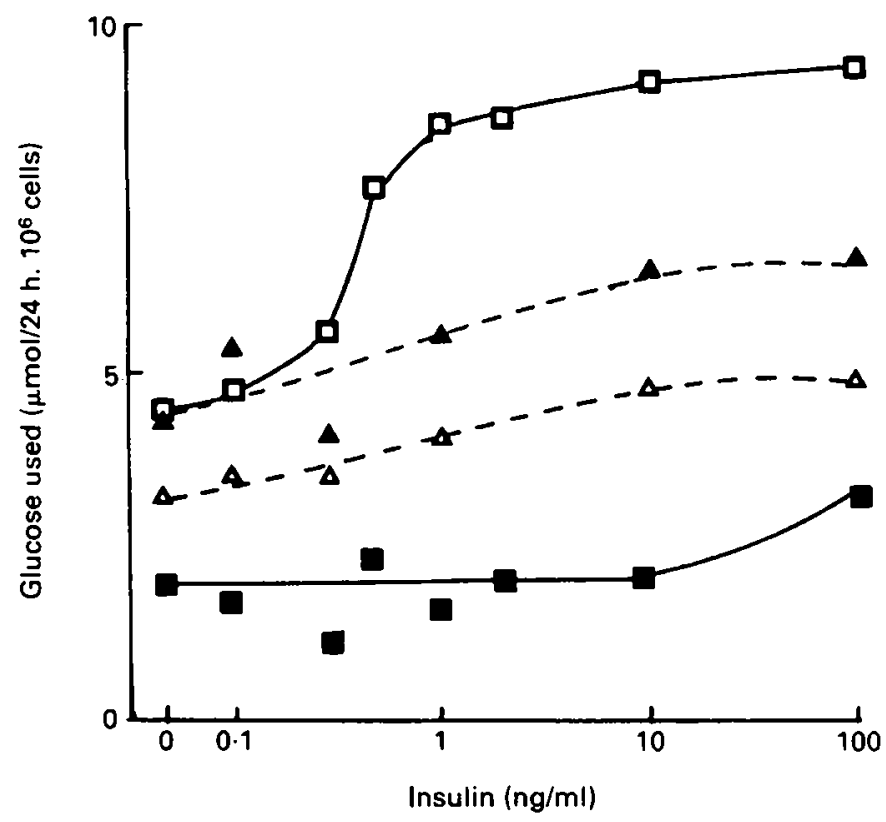

Fig. 2. Effect of insulin on glucose conversion to lactate $(\Delta, \Delta)$ and glucose conversion to products other than lactate $(\square, \square)$ in adipose tissue from non-lactating $(\triangle, \square)$ and lactating $(\Delta, \square)$ sheep. 
The mechanism responsible for the impaired insulin action in adipocytes during lactation is unknown. There appears to be no alteration in the number or affinity of insulin receptors of adipocytes from either rats (Flint et al. 1979) or sheep (Vernon et al. 1981; unpublished results) during lactation. Processing of the insulin-receptor complex following internalization is altered in adipocytes from lactating rats (Walker \& Flint, 1983), but this does not appear to be essential for activation of either pyruvate dehydrogenase or acetyl-CoA carboxylase (Jeffrey et al. 1985). A number of studies have suggested that insulin causes the release of a substance, possibly a phosphoinositolcontaining oligosaccharide, from the plasma membrane (Saltiel \& Cuatrecasas, 1986; Kelly et al. 1987; Mato et al. 1987). This putative mediator may be involved in the activation of pyruvate dehydrogenase by insulin, as well as a number of other enzymes including acetyl-CoA carboxylase (see Jarett \& Kiechle, 1984; Cheng \& Larner, 1985; Saltiel, 1987). In contrast, this factor does not appear to be involved in the stimulation of glucose transport by insulin (Kelly et al. 1987). We have found that the ability of the adipocyte plasma membrane to release this putative mediator is lost during lactation in rats (Kilgour \& Vernon, 1988). Failure to release this mediator from the plasma membrane in response to insulin, with a concomitant failure to activate key enzymes such as pyruvate dehydrogenase and acetyl-CoA carboxylase, but with retention of the ability of insulin to stimulate glucose transport, would account for the observations described previously and shown in Fig. 2.

The factors which produce the decreased responsiveness of adipocytes to insulin during lactation have not been defined. It is possible that the fall in serum insulin is involved, since several states that result in hypoinsulinaemia also result in a failure of plasma membranes to release the putative mediator in response to an insulin challenge (Kilgour \& Vernon, 1988). There is also circumstantial evidence to implicate prolactin, as decreasing serum prolactin concentration in lactating rats resulted in increased lipogenic activity (Agius et al. 1979; Flint et al. 1981) and in the number of insulin receptors of white adipocytes (Flint et al. 1981); the latter observation was unexpected for, as noted previously, the number of insulin receptors is not changed by lactation. It was also found that these effects of prolactin on adipocytes were dependent on a functioning mammary gland (Flint $e t$ al. 1981), which is consistent with the view that prolactin does not act directly on adipocytes. In contrast, we have found that growth hormone prevents the restoration of the ability of insulin to activate acetyl-CoA carboxylase in adipose tissue from lactating sheep (Vernon et al. 1988); this study also showed that restoration of insulin responsiveness was blocked by actinomycin $\mathrm{D}$, an inhibitor of transcription, suggesting that one or more proteins involved in the signal transduction pathway in adipocytes are lost during lactation.

Much less is known about insulin action in other tissues during lactation (apart from the mammary gland). Insulin activation of pyruvate dehydrogenase in rat liver in vivo appears to be unaltered by lactation in the rat (Kilgour \& Vernon, 1987). Indirect evidence suggests that the liver may become more sensitive to insulin during lactation (Burnol et al. 1986b), as may be inferred from the fact that glucose utilization and lipogenesis are increased while ketogenesis is depressed in rat liver (Table 2) despite the hypoinsulinaemia of lactation. This postulated increase in hepatic sensitivity to insulin is not associated with any change in the number or affinity of insulin receptors during lactation (Flint, 1980). In contrast, in the ruminant the hypoinsulinaemia will favour the high rates of hepatic gluconeogenesis and ketogenesis (Table 2). There is a decrease in both response and sensitivity for insulin stimulation of glucose utilization by the hind-limb of lactating sheep in vivo (Vernon, 1986) but, again, without any change in the number or affinity of skeletal-muscle insulin receptors (Metcalf et al. 1987). For the rat 
the picture is confusing, with the different muscles adapting in quite different ways: the soleus muscle, for example, appears to become more sensitive to insulin but with no change in maximum response to insulin, whereas the epitrochlearis muscle exhibits a diminished response to insulin (Burnol et al. 1987).

These various studies show that the response and sensitivity of tissues to insulin may change during lactation, that changes are tissue specific, and that the changes appear to be the result of alterations in signal transduction subsequent to the binding of insulin to its receptor. The effect of these adaptations is to further minimize the utilization of glucose and other lipogenic precursors in adipose tissue and glucose utilization in some muscles at least, and to ensure that there is little increase in utilization of such nutrients by these tissues in response to an insulin surge, for example following feeding, thereby facilitating the preferential utilization of glucose and lipogenic precursors by the mammary gland.

The mammary gland is also responsive to insulin in rodents (see Williamson, 1980; Zammit, 1985); acute effects of insulin have been observed on lipogenesis and protein synthesis but not on lactose synthesis (see Williamson, 1986). The mammary gland appears to be much more sensitive to insulin (Jones et al. 1984; Burnol et al. 1987) than adipose tissue and muscle, hence it is able to maintain high rates of insulin-sensitive processes during lactation despite the prevailing hypoinsulinaemia. The mechanism responsible for this enhanced sensitivity to insulin is unknown, but in contrast to the other tissues described previously, the number of insulin receptors of mammary epithelial cells is increased during lactation (Flint, 1982; Inagaki \& Kohmoto, 1982). As in adipocytes, liver and muscle, insulin also promotes the release of a putative second messenger from the plasma membrane of rat mammary cells (E. Kilgour and R. G. Vernon, unpublished results). One factor which may contribute to the increased sensitivity to insulin is a lack of response of the tissue to insulin antagonists. Thus, the rat mammary gland lacks glucagon receptors and so does not respond to this insulin antagonist (Robson et al. 1984). In ruminants, at least, there do not appear to be any growth hormone receptors on the mammary gland (Bauman \& McCutcheon, 1986), while although $\beta$-receptors are present on rat mammary cells the tissue shows little or no response to $\beta$-agonists, probably due to the very active cyclic AMP phosphodiesterase (EC 3.1.4.37) activity of the tissue (Clegg \& Mullaney, 1985).

In contrast to rodents, the mammary cells of ruminants appear to be impervious to acute effects of insulin (see Vernon, 1988) despite possessing insulin receptors (Oscar et al. 1986; Smith et al. 1986). The nature of this defect in signal transduction is not known, but it means that the hypoinsulinaemia of lactation has no consequences for the acute control of the mammary gland metabolism in these species. Thus, ruminants and rodents resolve the problem of hypoinsulinaemia for mammary metabolism in markedly different ways.

Whereas the ruminant mammary gland appears refractory to acute effects of insulin during lactation, there is a growing body of evidence suggesting that it responds to IGF-1. Receptors for IGF-1 are present (Campbell \& Baumrucker, 1986; Winder \& Forsyth, 1987) and infusion of IGF-1 into the pudic artery of goats for $4 \mathrm{~h}$ resulted in an increase in milk yield (Prosser $e$ e al. 1988). It is not known if IGF-1 has any direct effect on the mammary gland in rodents, but the demonstration that decreasing serum IGF-1 by lowering serum growth hormone had no effect on milk yield (Madon et al. 1986) would suggest that IGF-1 is not essential for mammary function in lactating rats. It is thus possible that in ruminants IGF-1 has adopted the role undertaken by insulin in rodents in the control of mammary gland metabolism. An increase in IGF-1 with concomitant effects on the mammary gland may thus be a major factor in the galactopoietic effects of 


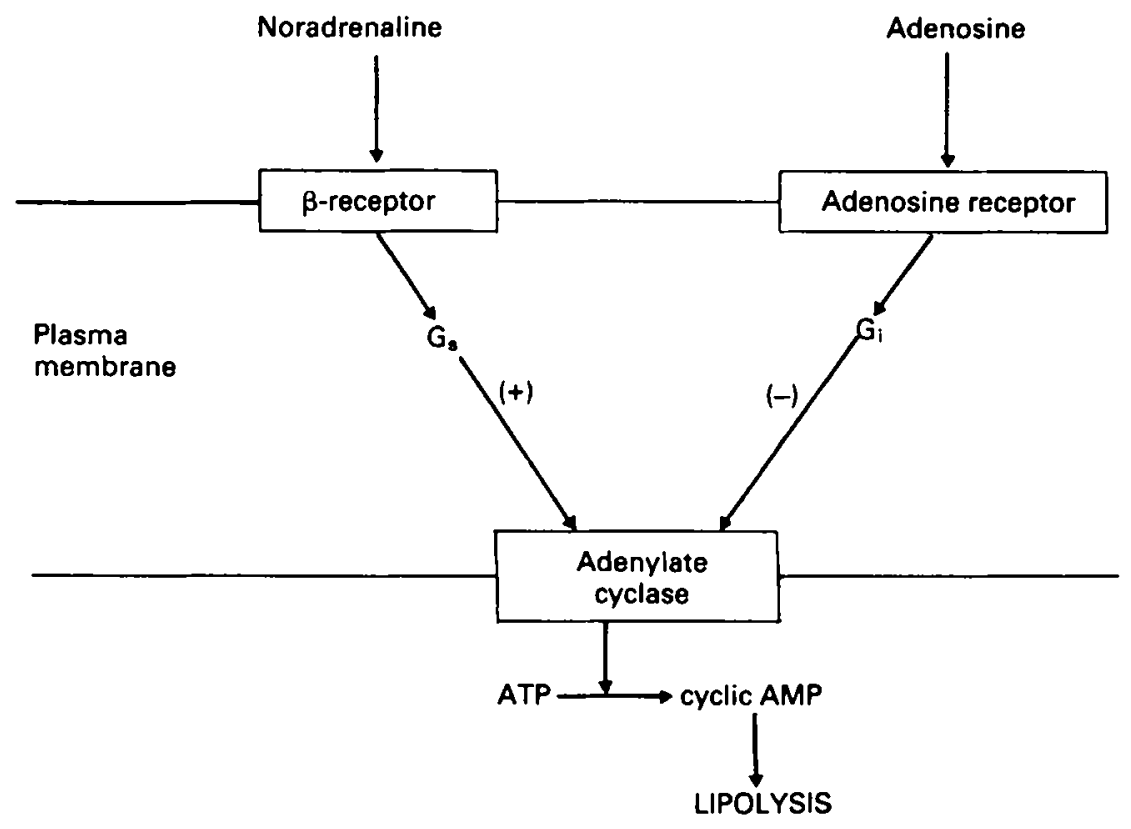

Fig. 3. Activation and inhibition of lipolysis by noradrenaline and adenosine. $G_{s}$ and $G_{i}, G T P$-binding proteins; $(+),(-)$, stimulation and inhibition respectively.

growth hormone in ruminants which, as noted previously, is not thought to act directly on the gland itself. In the rat at least there do not appear to be any IGF-1 receptors on adipocytes (Massague \& Czech, 1982), whilst in ruminants effects of IGF-1 on lipogenesis in adipose tissue require high concentrations of the hormone, suggesting that it was acting via the insulin receptor (Etherton \& Evock, 1986; R. G. Vernon and E. Finley, unpublished results). Thus elevation of serum IGF-1 during lactation should not have any deleterious effects on nutrient partitioning, at least as far as the mammaryadipose axis is concerned.

Catecholamine action. Stimulation of the sympathetic nervous system causes the release of noradrenaline which stimulates lipolysis (Fig. 3) in all adipose tissues as well as thermogenesis in brown adipose tissue. As noted previously, sympathetic nervous activity is decreased in brown adipose tissue of lactating rats, but it is not known if there is any change in sympathetic nervous activity in white adipose tissue in any species during lactation; a decrease would seem unlikely in view of the increased lipolysis.

The maximum response of adipose tissue to the lipolytic effect of catecholamines is increased during lactation in cattle and sheep (see Vernon, 1988) but not in rats (Aitchison et al. 1982). In cattle at least, there is an increase in the number of $\beta$-catecholamine receptors of adipocytes during lactation (Jaster \& Wegner, 1981) which could account for the increased response to noradrenaline.

Growth hormone is implicated in the increased response of adipocytes to catecholamines, as treatment of cattle with growth hormone resulted in an apparent increase in lipolytic response to noradrenaline in vivo (McCutcheon \& Bauman, 1986), while preliminary studies with sheep adipose tissue show that maintenance in tissue culture for $48 \mathrm{~h}$ with growth hormone results in an increase in $\beta$-receptor binding (P. R. Watt and R. G. Vernon, unpublished results). In addition, whilst lactation itself had no effect on 
the lipolytic response to noradrenaline in the rat, the response decreased markedly on removal of the litter (Vernon \& Finley, 1986) (litter removal results in a period of lipid accretion). This change could be induced by depressing serum growth hormone in lactating rats and prevented by injecting growth hormone into rats on litter removal (Vernon et al. 1987). In contrast, varying serum prolactin concentration had no effect on the response of adipocytes to noradrenaline (Vernon \& Finley, 1986). These observations all point to a role for growth hormone in the modulation of adipocyte response to catecholamines. Thus, the increased response observed in lactating ruminants but not in lactating rats may well be due to the increase in serum growth hormone found in the former but not in the latter during lactation.

Adenosine action. Adenosine is produced in most tissues, including adipose tissue where it acts on adipocytes to inhibit lipolysis (Fig. 3). From a consideration of insulin and catecholamine action, one might expect adipocytes to become less responsive to adenosine during lactation but, paradoxically, in both rats (Vernon et al. 1983) and sheep (Vernon \& Finley, 1985) the tissue shows a greater response to adenosine; the physiological advantage of this adaptation is not obvious. The factors controlling the response to adenosine have not been identified, but growth hormone is again implicated in the rat at least. Lowering or raising serum growth hormone in lactating rats increased and diminished the response to adenosine respectively (Vernon et al. 1987), but this in itself does not explain the increased response to adenosine during lactation as serum growth hormone does not change in the rat, while in sheep the response to adenosine increases at a time when serum growth hormone is increased. Following litter removal, administration of growth hormone decreased the response to adenosine to a greater extent than in rats suckling their young (Vernon et al. 1987) suggesting that some factor is operating during lactation to antagonize the ability of growth hormone to restrict the response of adipocytes to adenosine: the identity of this factor is unknown although prolactin, at least, can be excluded (Vernon et al. 1987).

\section{Conclusions}

Lactation requires both an increased supply of nutrients and also development of mechanisms which ensure the preferential utilization of nutrients by the mammary gland. This challenge is met successfully in both rodents and ruminants, but although the strategies adopted by these two groups of species show some similarities there are also some very marked differences. A combination of hypoinsulinaemia and diminished responsiveness to insulin in adipose and muscle tissue are used by both types to favour the preferential utilization of nutrients by the mammary gland. On the other hand, the differences in absorbed nutrients requires very different adaptations of liver metabolism in the two types of animal; the hypoinsulinaemia favours increased gluconeogenesis in ruminants, whereas in the rat it would appear that the liver becomes more sensitive to insulin in view of the high rates of glucose utilization despite hypoinsulinaemia. In contrast, the mammary gland has resolved the problem of hypoinsulinaemia by very different strategies, the reason for which is not apparent, with an increased sensitivity in the rat to the hormone, whereas in the ruminant the gland appears refractory to the hormone, at least in the short-term, and may be more dependent on IGF-1 for its acute control; these differences may be related to the relative importance of prolactin and growth hormone for maintaining lactation in the two types of animal.

\section{REFERENCES}

Agius, L., Robinson, A. M., Girard, J. R. \& Williamson, D. H. (1979). Biochemical Journal 180, 689-692.

Aitchison, R. E. D., Clegg, R. A. \& Vernon, R. G. (1982). Biochemical Journal 202, 243-247. 
Bauman, D. E. \& Elliot, J. M. (1983). In Biochemistry of Lactation, pp. 437-468 [T. B. Mepham, editor]. Amsterdam: Elsevier.

Bauman, D. E. \& McCutcheon, S. N. (1986). In Control of Digestion and Metabolism in Ruminant Animals, pp. 436-455 [L. P. Milligan, W. L. Grovum and A. Dobson, editors]. Englewood Cliffs, NJ: Prentice-Hall.

Burnol, A.-F., Ferré, P., Leturque, A. \& Girard, J. R. (1987). American Journal of Physiology 15, E183-E188.

Burnol, A.-F., Guerre-Millo, M., Lavau, M. \& Girard, J. R. (1986a). FEBS Letters 194, 292-296.

Burnol, A.-F., Leturque, A., Ferré, P. \& Girard, J. R. (1983). American Journal of Physiology 245, E351-E358.

Burnol, A.-F., Leturque, A., Ferré, P., Kande, J. \& Girard, J. R. (1986b). American Journal of Physiology 251, E537-E541.

Campbell, P. G. \& Baumrucker, C. R. (1986). Journal of Dairy Science 69, Suppl. 1, 163.

Cheng, K. \& Larner, J. (1985). Annual Review of Physiology 47, 405-424.

Clegg, R. A. \& Mullaney, I. (1985). Biochemical Journal 230, 239-246.

Collier, R. J., McNamara, J. P., Wallace, C. R. \& Dehoff, M. H. (1984). Journal of Animal Science 59, 498-510.

Etherton, T. D. \& Evock, C. M. (1986). Journal of Animal Science 62, 357-362.

Ferré, P., Burnol, A.-F., Leturque, A., Terretaz, J., Penicaud, L., Jeanrenaud, B. \& Girard, J. (1986). Biochemical Journal 233, 249-252.

Flint, D. J. (1980). Biochimica et Biophysica Acta 628, 322-327.

Flint, D. J. (1982). Molecular and Cellular Endocrinology 26, 281-294.

Flint, D. J., Clegg. R. A. \& Vernon, R. G. (1981). Molecular and Cellular Endocrinology 22, $265-275$.

Flint, D. J., Sinnett-Smith, P. A., Clegg, R. A. \& Vernon, R. G. (1979). Biochemical Journal 182, $421-427$.

Forsyth, I. A. (1986). Joumal of Dairy Science 69, 886-903.

Garlick, P. J. (1986). International Journal of Vitamin and Nutritional Research 56, 197-200.

Girard, J., Burnol, A.-F., Leturque, A. \& Ferré, P. (1987). Biochemical Society Transactions 15, $1028-1030$.

Hansson, P., Newsholme, E. A. \& Williamson, D. H. (1987). Biochemical Journal 243, 267-271.

Inagaki, Y. \& Kohmoto, K. (1982). Endocrinology 110, 176-182.

Jarett, L. \& Kiechle, F. L. (1984). Vitamins and Hormones 41, 51-78.

Jaster, E. H. \& Wegner, T. N. (1981). Journal of Dairy Science 64, 1655-1663.

Jeffrey, I. W., Flint, D. J., Vernon, R. G. \& Mayer, R. J. (1985). FEBS Letters 182, 451-454.

Jones, R. G., Ilic, V. \& Williamson, D. H. (1984). Biochemical Journal 220, 455-460.

Kelly, K. L., Mato, J. M., Merida, I. \& Jarett, L. (1987). Proceedings of the National Academy of Sciences, USA 84, 6404-6407.

Kilgour, E. \& Vernon, R. G. (1987). Biochemical Journal 243, 69-74.

Kilgour, E. \& Vernon, R. G. (1988). Biochemical Journal 252, 667-672.

Lomax, M. A., Baird, G. D., Mallinson, C. B. \& Symonds, H. W. (1979). Biochemical Journal 180, $281-289$.

McCutcheon, S. N. \& Bauman, D. E. (1986). Jourmal of Dairy Science 69, 44-51.

Madon, R. J., Ensor, D. M. \& Flint, D. J. (1985). Biochemical Society Transactions 13, 878-879.

Madon, R. J., Ensor, D. M., Knight, C. H. \& Flint, D. J. (1986). Journal of Endocrinology 111, $117-123$.

Massagué, J. \& Czech, M. P. (1982). Journal of Biological Chemistry 257, 5038-5045.

Mato, J. M., Kelly, K. L., Abler, A. \& Jarett, L. (1987). Journal of Biological Chemistry 262, 2131-2137.

Metcalf, J. A., Vernon, R. G., Flint, D. J. \& Weekes, T. E. C. (1987). Proceedings of the Nutrition Society 46, $47 \mathrm{~A}$.

Millican, P. E., Vernon, R. G. \& Pain, V. M. (1987). Biochemical Journal 248, 251-257.

Nicoll, C. S., Anderson, T. R., Herbert, N. J. \& Russell, S. M. (1985). In Prolactin, Basic and Clinical Correlates, pp. 392-410 [R. M. MacLeod, M. O. Thorner and U. Scapagnini, editors]. Padua: Liviana Press.

Oscar, T. P., Baumrucker, C. R. \& Etherton, T. D. (1986). Journal of Animal Science 62, 179-186.

Prosser, C. G., Fleet. I. R., Corps, A. N., Heap, R. B. \& Froesch, E. R. (1988). Journal of Endocrinology 117, Suppl., 248A.

Robson, N. A., Clegg, R. A. \& Zammit, V. A. (1984). Biochemical Journal 217, 743-749.

Saltiel, A. R. (1987). Endocrinology 120, 967-972.

Saltiel, A. R. \& Cuatrecasas, P. (1986). Proceedings of the National Academy of Sciences, USA 83, 5793-5797.

Schalch, D. S. \& Reichlin, S. (1966). Endocrinology 79, 275-280.

Siebrits, F., Martinez, J. A. \& Buttery, P. J. (1985). International Journal of Biochemistry 17, 731-732. 
Smith, D. H., Palmquist, D. L. \& Schanbacher, F. L. (1986). Comparative Biochemistry and Physiology 85A, 161-169.

Trayhurn, P. (1985). International Journal of Obesity 9, Suppl. 2, 81-88.

Trayhurn, P. \& Jennings, G. (1987). Biochemical Journal 248, 273-276.

Trayhurn, P. \& Wusteman, M. C. (1987). American Journal of Physiology 253, E515-E520.

Vernon, R. G. (1986). Hannah Research 1985, pp. 115-121.

Vernon, R. G. (1988). In Nutrition and Lactation in the Diary Cow, pp. 32-52 [P. C. Garnsworthy, editor]. London: Butterworths.

Vernon, R. G., Barber, M., Finley, E. \& Grigor, M. R. (1988). Proceedings of the Nutrition Society 47, 100A.

Vernon, R. G., Clegg, R. A. \& Flint, D. J. (1981). Biochemical Journal 200, 307-314.

Vernon, R. G. \& Finley, E. (1985). Biochemical Journal 230, 651-656.

Vernon, R. G. \& Finley, E. (1986). Biochemical Journal 234, 229-231.

Vernon, R. G., Finley, E. \& Flint, D. J. (1987). Biochemical Journal 242, 931-934.

Vernon, R. G., Finley, E. \& Taylor, E. (1983). Biochemical Journal 216, 121-128.

Vernon, R. G. \& I lint, D. J. (1984). Symposium of the Zoological Society of London 51, 119-145.

Walker, A D \& Flint, D. נ. (1983). Biochemical Journal 210, 373-378.

Weiner, J. (1987). In Reproductive Energetics in Mammals, pp. 167-187 [A. S. I. Loudon and P. A. Racey, editors]. Oxford: Clarendon Press

Williamson, D. H. (1980). FEBS Letters 118, K93-K105.

Williamson, D. H. (1986). Reproduction, Nutrition, Développement 26, 597-603.

Winder, S. J. \& Forsyth, I. A. (1987). Journal of Endocrinology 112, Suppl., 64A.

Zammit, V. A. (1985). Biochemical Society Transactions 13, 831-833. 